\title{
SUSPECTS, DEFENDANTS AND VICTIMS IN THE FRENCH CRIMINAL PROCESS: THE CONTEXT OF RECENT REFORM
}

\author{
JACQUELINE HODGSON*
}

\section{INTRODUCTION: THE CONTEXT OF REFORM}

The recent reform adopted by the French Parliament, the Loi of 15 June 2000, touches upon a wide range of matters from investigation and detention through to trial and appeal, all within a project designed to 'reinforce the presumption of innocence and the rights of victims' ${ }^{1}$ It is part of a broader reform package which originally included strengthening the independence of the procureur ${ }^{2}$ from the hierarchical control of the Minister of Justice and changing the way in which magistrats ${ }^{3}$ are selected, ${ }^{4}$ together with the measures already enacted in June of 1999 to simplify and clarify aspects of criminal procedure and to reduce delay. ${ }^{5}$ A large part of the June 2000 reform seeks to strengthen the rights of the accused and the safeguards designed to ensure her proper treatment at all stages of the criminal process. Such rhetoric and aspirations stand in contrast to the Home Office and government discourse to which we have become accustomed on this side of the Channel, a discourse dominated by macho language expressing a desire to 'get tough' and 'crackdown' on crime and presumed criminals. ${ }^{6}$ Against the backdrop of almost mandatory defence disclosure and the curtailment of the right to silence in this jurisdiction, provisions which strengthen the rights of the accused and provide her with more

\footnotetext{
* School of Law, University of Warwick.

1 Loi no 2000-516 du 15 juin 2000 renforçant la protection de la présomption d'innocence et les droits des victimes.

2 The state prosecutor.

3 The career trained judiciary of the procureur, the juge d'instruction and the trial judge.

4 These two reforms required a constitutional amendment and so a three-fifths majority vote in Parliament. Although enjoying broad political support to begin with, this was withdrawn at the last moment and the special sitting of Parliament due to take place in January 2000 was cancelled by the President, Jacques Chirac.

5 Loi no 99-515 du 23 juin 1999 renforçant l'efficacité de la procédure pénale. This legislation establishes a wide range of alternatives to prosecution (France's so called 'third way') which the procureur can propose to the accused. They include measures such as the issuing of a formal warning; requiring the accused to carry out up to 60 hours of unpaid work for the community; suspension of a driving or hunting licence for up to 4 months; and paying compensation to the victim. The accused may consult with a lawyer before deciding whether or not to accept the suggested alternative to prosecution. Although no prosecution can be brought, if the victim is later identified, she may claim compensation before the criminal court in the same way as if a prosecution had been brought.

6 See, eg, F Belloni and J Hodgson, Criminal Injustice: An Evaluation of the Criminal Justice Process in Britain (Basingstoke: Macmillan, 2000), ch 10.
} 
information about the case against her together with greater opportunities to influence the pre-trial investigation, will make English criminal justice scholars nostalgic for a time when the rights of the accused were seen as something other than 'a criminal's charter'.

Yet, welcome though these reforms are, they must be seen in the context of the very different process of criminal justice in place in France: one where (until the passing of these reforms) the police were not obliged to tell the suspect either of her right to silence or of the nature of the enquiry in connection with which she was being held; where the suspect held in police custody had access to a defence lawyer only after 20 hours of detention and then, for only half an hour (an arrangement which meant that in practice, less than 10 per cent of people held in garde à $v u e^{7}$ were able to consult with their lawyer) ${ }^{8}$ and where there was no appeal against conviction for the most serious offences, crimes, ${ }^{9}$ tried in the cour d'assises. Even taking into account the different historical roots and legal culture of French criminal justice, ${ }^{10}$ these were significant deficiencies. In many instances the reforms do little more than bring France into line with most other European countries and ensure compliance with the European Convention on Human Rights (ECHR) as required by Article 55 of the French Constitution. For example, the reform of Article 63-1 code de procédure pénale $(\mathrm{CPP})^{11}$ requiring the police to inform the suspect of the reasons for her detention in police custody is necessary in order to comply with Article 5(2) of the European Convention, which states that: 'Every person arrested must be informed promptly and in a language that they understand the reasons for their arrest and of any charges against them.' Similarly, the provision of translators at all stages of the criminal process is a basic ECHR requirement. Other reforms relate more directly to condemnations before the Court, concerning the ways in which accused persons have been treated within the French criminal process. France has one of the highest levels of litigation before the European Court ${ }^{12}$ and much of it concerns the length of time suspects spend on remand in prison while the investigation is

\footnotetext{
7 This is the term used to describe the period of police detention.

8 According to the then Justice Minister, Mme Guigou in her address to the Sénat, 15 June 1999.

9 Offences are classed as crimes (the most serious, such as murder); délits (such as assault or burglary) and contraventions (the least serious). These classifications represent a hierarchy of gravity and will determine the trial venue.

10 See further, J Hodgson, 'The police, the prosecutor and the juge d'instruction: Judicial Supervision in France, Theory and Practice' (2001), British Journal of Criminology 41(2), 342-61; J Bell, French legal Cultures (London: Butterworths, 2001); P Legrand (1996) 'European Legal Systems are not Converging' (2001) ICLQ, 52. On the dangers of glib comparisons, J Hodgson, 'Comparing Legal Cultures: The Comparativist as Participant Observer', in D Nelken (ed), Contrasting Criminal Justice (Aldershot: Ashgate, 2000), 139-56. On the importance of legal culture, see also D Nelken, Comparing Legal Cultures (Aldershot: Dartmouth. 1997).

11 All articles refer to the CPP unless otherwise indicated.

12 Although only allowing the right of individual petition since 1981, France has been condemned by the European Court on more than seventy occasions. Only Italy exceeds this.
} 
ongoing, before any decision to prosecute has been taken. Famously, in the case of Tomasi $v$ France a detention period of over five and a half years before acquittal was held to be unjustified. ${ }^{13}$ This has been a long-standing thorn in the side of Justice Ministers and the current reform introducing the juge des libertés et de la détention (JLD) to decide issues of detention during investigation, like its short-lived 1993 predecessor the juge délegué, is designed to go some way to alleviate the problem.

The treatment of those appealing to the Cour de cassation $^{14}$ has also come in for sharp criticism. Under Article 583, unless special dispensation had been granted, appellants to the Cour de cassation were obliged to surrender themselves into custody the day before their hearing took place. Failure to do so resulted in the automatic rejection of the appeal. Despite repeated condemnations by the European Court, on the grounds that this was an excessive penalty to impose upon appellants, the French courts continued to apply the rule. ${ }^{15}$ Criticising the measure as archaic and clearly unable to prevent flight from the jurisdiction in any event, ${ }^{16}$ the then Justice Minister Elisabeth Guigou announced in October 1999 that appellants would no longer be required to surrender themselves to the court and Article 583 has now been amended accordingly.

Another major plank of the June 2000 reform which responds directly to France's failure to take account of decisions of the European Court, is that concerning the re-examination of cases successfully brought by individuals who claim that they were treated unfairly in some way. France was heavily criticised for its refusal to re-open a case after it had been condemned in 1997 under the ECHR for failing to respect the rights of the defence: ${ }^{17}$ Abdelhamid Hakkar was convicted in his absence and without defence representation, of murdering a police officer. ${ }^{18}$ The only other European country failing to re-open a case

13199315 EHRR 1. For other examples, see J Bell, 'The French Pre-Trial System, in C Walker a K Starmer' (eds), Miscarriages of Justice: A Review of Justice in Error (London: Blackstone Press, 1999), 354-70 at 365 n 35; Bell, (above at n 10), at 111; J-P Marguénaud (2000) 'La dérive de la procédure pénale française au regard des exigences européennes' Dalloz (Chroniques), 249-55.

14 This court hears appeals on a point of law. Exceptionally and with the leave of a special commission of five judges, the court can act as a full appeal court if, as a result of new evidence, there is a prima facie case that a judicial error has been made.

15 See, eg, Poitrimol ECHR 23 Nov 1993; Omar and Guérin ECHR 29 July 1998; Khalfaoui ECHR 14 Dec 1999. Like the celebrated instance of Maurice Papon, M Khalfaoui had requested and been refused special dispensation not to appear. See further J-P Delmas Saint Hilaire (2001) 'Affaire Maurice Papon. La justice pénale française avait encore des choses à dire . . . Deux étranges non-lieux à statuer', Dalloz, (Jurisprudence), 3222.

16 Referring to the case of Maurice Papon, who failed to appear before the court having fled the country.

17 See, eg, the discussion reported in Le Monde 16 Feb 2000. See also Reinhardt and Slimane Kaïd v France ECHR 31 Mar 1998; Slimane Kaïd v France ECHR 25 Jan 2000; Voisin v France ECHR 8 Feb 2000.

18 The right to legal representation, even where the defendant is absent, has now been accepted by the full chamber of the Cour de cassation in the case of Dentico heard on 2 Mar 2001 $(00-81.388$, No $473 \mathrm{P})$. This reverses a long line of decisions and is significant in holding that Art 
considered unfair under the ECHR is Turkey. The June reform finally amended Article 626 to ensure that in future, such cases can be re-opened at the request of any of the parties involved.

In these instances, the rights-based language of the reform and the abrogation of important and contentious articles in the CPP, have been brought about not through a closed and internally generated desire for change and innovation, but rather, through a wider political necessity, in order to avoid continued criticism and condemnation under the ECHR. ${ }^{19}$ But this is not to undercut their significance. There is no doubt that these reforms represent a milestone in criminal justice and to show how serious she was about them, the Minister of Justice took the unusual step of securing the necessary resources before moving to legislation, thus ensuring that provisions would not be undermined through an inadequate infrastructure. ${ }^{20}$ The 1993 reforms, for example, which established for the first time the right of suspects to consult with a lawyer at the police station, rang a little hollow when lawyers immediately went on strike and refused to attend because no proper financial provision had been made for those providing custodial legal advice. The Minister has also established a working party to monitor the success of these reforms and to report on the potential for expanding measures such as the videotaping of interrogations. $^{21}$ The reforms are a major achievement in moving on the due process

410 CPP (which allows the case to be heard in the defendant's absence) is contrary to Art 6 ECHR if the defence is unrepresented. See Jean Pradel's case note (2001) 'Le prévenu cité à personne, absent, et non excusé, a droit néanmoins à l'assistance d'un avocat.' Dalloz (Commentaires) (24), 1899-1901.

19 See further, Marguénaud, 2000 (above n 13) for a discussion of some of the most important findings against France which, he argues, demonstrate the growing discrepancy between the realities of domestic practice and the way in which France presents itself to the outside world. He notes the 'arrogant' attitude of the higher courts and the legislature to the decisions of the European Court in Strasbourg. See also J Pradel (2000) 'La procédure pénale française à l'aube du troisième millénaire', Dalloz (Chroniques) (1), 1-9.

20 There have been continuous complaints that resources remain woefully insufficient and magistrats have protested, throwing their codes de procédure pénale at the windows of the Ministry of Justice (19 Jan 2001) and organising days of action in March and November 2001. An aditional 1,200 magistrats and 2,500 assistants have been promised between now and 2005. This has not quelled criticism on the part of police and magistrats concerning the acute shortage of material resources and personnel. See, eg, the police demonstration in Oct 2001 and the petition of juges d'instruction in December 2001.

21 The first report on the application of the June 2000 reform was published in December 2000 and resulted in a delay of the application of some provisions relating to the juge de l'application des peines. The second was published in June 2001. See J-P Collomp (Inspecteur général des services judiciaires) (2001) Rapport de la mission sur l'application de la loi du 15 juin 2000 relative au renforcement de la protection de la présomption d'innocence et des droits des victimes Paris: Ministère de la Justice. In the face of mounting unease on the part of police (who dubbed the reform, the 'hooligan's law'), the MP Julien Dray was commissioned to gather professional opinion on the reform's impact on the work of the police and gendarmes. Published in December 2001 (Evaluation de l'application et des conséquences sur le déroulement des procédures diligentées par les services de police et de gendarmeries des dispositions de la loi du 15 juin 2000 renforçant la protection de la présomption d'innocence et les droits des victimes Rapport pour le Premier Ministre, 19 Dec 2001) most of the recommendations in the report were adopted and the 
aspects of French criminal procedure and changing the rhetoric of criminal justice. It is a discourse very much influenced by, and which now takes more seriously, the jurisprudence of the ECHR. Whilst the procedure essentially remains faithful to its inquisitorial roots, ${ }^{22}$ notions of equality of arms and of open debate are increasingly cited as guarantees of fairness and incorporated into the various stages of criminal procedure. ${ }^{23}$ In introducing and defending her reform project, the then Justice Minister Elisabeth Guigou made frequent reference to the importance of the rights of the defence in any fair and equitable criminal process and the need to balance these against the effectiveness of the criminal investigation. ${ }^{24}$ These are no longer portrayed as mutually contradictory, ${ }^{25}$ but as complementary principles: affording the accused greater protections is seen to enhance the fairness of the procedure and so, ultimately, to legitimate the investigation and trial process.

However, given the monist approach of the French legal system to international law obligations under Article 55 of the Constitution, it is interesting that many of the most fundamental Convention guarantees now considered sufficiently important to merit the attention of the legislator, have been neither litigated nor legislated previously. ${ }^{26}$ This appears to be the result of some degree

June 2000 law amended by parliament at the beginning of 2002. The government has said that it will not be expanding the use of videotapes to adult suspects.

22 Madame Guigou, the then French Minister of Justice, made clear her views when addressing the Sénat in June of 1999: 'The adversarial system of justice is by nature unfair and unjust. It favours the strong over the weak. It accentuates social and cultural differences, favouring the rich who are able to engage and pay for the services of one or more lawyers. Our own system is better, both in terms of efficiency and of the rights of the individual.'

23 The principle of contradictoire, as it is known, is seen, for example, in the introduction of public bail hearings (for détention provisoire during instruction); public hearings before the chambre d'instruction (formerly the chambre d'accusation) at the request of the accused, unless this threatens the security of the instruction or a third party; and the ability of the lawyers representing the parties to question directly witnesses at court.

24 Compare the opening paragraphs of the preliminary report of the Delmas-Marty Commission in 1989 (established because of concern over the impact of the ECHR upon French criminal procedure): 'But the whole difficulty of criminal procedure . . . is that efficiency, no matter how necessary it is, cannot be pursued at any price. Even though torture may make a guilty person confess, it is clear that this could not justify its use. Moreover, constitutional principles such as international agreements undertaken by France, require that the efficiency of the process be subject to the respect of the fundamental rights of the individual. In fact, this double imperative . . . is not necessarily antagonistic and it would be better to talk about the 'bipolarity' of the criminal process', M Delmas-Marty, La mise en état des affaires pénales: Rapport de la Commission Justice pénale et Droits de l'homme (Paris: La Documentation Française,1991), 11-12. Interestingly, the most recent circular (10 Jan 2002) to be issued by the Ministry on Justice (in response to sustained protest by the police and gendarmes concerning the difficulties in implementing the June 2000 reform) is phrased not in terms of the effectiveness of the investigation, but sees a return to rhetoric which speaks of the necessity for la répression.

25 See, eg, C Vroom (1988) 'La liberté individuelle au stade de l'enquête de police en France et aux Etas-Unis.' Revue de science criminelle et de droit pénal comparé (3), 487-507, who describes the underlying values of the French criminal process in crime control terms: the freedom of the individual is best protected through the provision of broad legal powers for the repression of crime.

${ }^{26}$ I am grateful to an $I C L Q$ reviewer for suggesting that this point be expanded upon. 
of reticence at the level of individual legal actors, the appellate court and the state. In the course of my own empirical research, ${ }^{27}$ I found that whilst the ECHR was part of the professional discourse of magistrats and defence lawyers, this was often understood in dilute and minimalist terms. The willingness to litigate these Convention guarantees and rely upon them in the domestic courts does not seem to be a firmly established part of the expectations or culture of legal actors. Furthermore, whilst the defence rights of the suspect held in garde à vue may be paramount to the observer from a more adversarial jurisdiction, magistrats and even defence lawyers in France continue to subscribe to a traditional view of inquisitorial criminal procedure, which casts the police enquiry as relatively unimportant, yielding only preliminary information which must be confirmed by a magistrat before it attains the status of evidence. ${ }^{28}$ For them, the procedure only really begins once the magistrat has the dossier and so it is only then that defence rights, such as reminding the accused of her right to remain silent, are required to come into play. This reflects neither the experience of the suspect who may be detained in police custody for up to 48 hours, nor the realities of criminal investigations which are dominated by the police and involve the juge d'instruction in only 7 per cent of cases.

This reluctance and conservatism towards innovating change is also reflected at the higher level of appeal court decisions and legislative change. The assimilation of Convention guarantees into national law and jurisprudence has not progressed at a uniform speed. After the enthusiasm of the early years following the right of French citizens to petition the court directly and having reached something of a pinnacle of achievement with the passing of the 1993 reforms,${ }^{29}$ the attitude of the courts and the legislature is described as one of increasing cynicism and arrogance. ${ }^{30}$ Rather than generating wider changes in practice and approach, the application of European Court decisions has often been limited to the individual case in point. The policy of the Cour de cassation in particular, seems to have been one of resistance to the supranational effect of Convention law and a preference for the preservation of judicial autonomy and national sovereignty. ${ }^{31}$ However, this position has become

27 A study conducted during 1997-9 and funded by the Leverhulme Trust, examining the investigation and prosecution of crime in France. A smaller study funded by the British Academy and the Nuffield Foundation was conducted in 1993-4. For details of the methodology see Hodgson (above n 10), 349.

28 This reflects the idea that criminal procedure has three distinct phases-instruction, prosecution and trial. The dominant role of the police, be it through gathering initial evidence for the procureur or carrying out the investigation for the juge d'instruction through the delegated powers of the commission rogatoire procedure, is not recognised in this characterisation. I was frequently told that whatever witnesses or suspects said to the police could later be retracted and it was only what took place before the magistrat which was considered important.

29 It should be recalled that the Delmas-Marty Commission, 1991 (above n 24) which preceded the reform, was required to report on the compatibility of French criminal procedure with the European Convention.

30 See Marguénaud (above n 13)

31 This may also be exacerbated by the increasingly interventionist stance taken by the Court (Marguénaud (above n 13)) argues this generally. J-F Burgelin, (2001) 'La Cour de cassation en 
difficult to sustain as the cumulative effect of European Court decisions extends beyond the criticism of individual cases or procedural errors and increasingly, implicates the wider criminal process and faults which are endemic to it, such as lack of respect for defence rights, ${ }^{32}$ police brutality and excessive delays in bringing the accused to trial. It would seem that the French monist approach, whilst able to effect minor adjustments through the decisions of the Cour de cassation, is unable to ensure the kind of structural and systematic changes which ECHR jurisprudence now demands and which the June 2000 project has sought to achieve. ${ }^{33}$ In this way, it is not so very different from the experience in England and Wales, where we have witnessed government hostility to European Court decisions (notably those relating to Northern Ireland $)^{34}$ and the law has only gradually been changed where required. ${ }^{35}$ The UK courts, though recognising the formal position of non-incorporation of the ECHR into domestic law, ${ }^{36}$ have been increasingly (if not always explicitly) influenced by the Convention and the jurisprudence of the European Court. ${ }^{37}$ The passing of the Human Rights Act 1998 is unlikely to add very much to the Police and Criminal Evidence Act 1994 (PACE) and related legislation in terms of concrete 'rights', particularly given the wide 'margin of appreciation' 38 afforded member states in matters of evidence. ${ }^{39}$ What it may provide,

question', Dalloz (12), 932-4 fears that the European Court is becoming an additional level of appeal, blurring the role of the Cour de cassation. He muses whether, just as the Euro has replaced the franc, the European Court will replace the Cour de cassation. (H Fenwick, Civil LibertiesNew Labour, Freedom and the Human Rights Act (Harlow: Longman, 2000), also notes the impact of the decision in Condron v UK [2000] JCIV LIB 253 upon the role of the Court of Appeal.) This trend is unlikely to abate since the disappearance of the Commission as a preliminary filter on cases with the coming into force of Protocol 11 in Nov 1998.

32 See Marguénaud (above n 13) and for a recent 'softening' of approach, see discussion above, n 18.

33 Interestingly, whilst it has been condemned on a number of points, described above, it is not the case that France has been obviously in breach of the Convention in relation to, eg, the suspect's access to a defence lawyer. Nor has the institution of the juge d'instruction been condemned as characterising an unacceptable conflict of interest between investigation and judicial roles, though the opportunity for debate between the procureur and the defence was required in détention provisoire decisions. Yet, these are areas where the need for reform has been recognised. This was again noted by the Justice Minister, Marylise Lebranchu, who described the old procedure of detention as archaic and in need of reform, in order that France was no longer seen as the 'mauvais élève de l'Europe' (Discours de Marylise Lebranchu, 22 Jan 2002).

34 Notably McCann v UK (1995) 21 EHRR 97. In response to the Court's condemnation under Art 5(3) of the detention of a terrorist suspect for 4 days and 6 hours (Brogan $v$ UK (1989) 11 EHRR 117) the government did not alter the law, but simply re-entered a derogation from Art 5(3) under Art 15. This derogation was upheld in Brannigan and McBride v UK (1993) 17 EHRR 594.

$35 \mathrm{eg}$, the Interception of Communications Act 1985 followed from the decision in Malone $v$ UK (1984) 7 EHRR 14, where the Court found a breach of Art 8.

${ }^{36} R v$ Secretary of State for the Home Department, ex parte Brind [1991] AC 696.

37 See D McGoldrick (2001) 'The United Kingdom's Human Rights Act 1998 in Theory and Practice.' ICLQ, 50(4), 901-53, 904.

38 See, eg, discussion in Fenwick (above, n 31), 27-9.

39 See Edwards v UK A 247-B (1992). In Schenk $v$ Switzerland (1988) 13 EHRR 242, no breach of Art 6(2) was found when an illegally obtained tape recording was admitted as evidence. Cf the later case of Teixeira de Castro v Portugal (1999) 28 EHRR 101, where the Court held that 
however, is a firm underpinning to existing due process rights and clearer normative standards of what amounts to a fair trial, which should be taken into account in the exercise of judicial discretion to exclude evidence under section 78 PACE. ${ }^{40}$ In both jurisdictions, despite the different systems of incorporation, it has been largely the approach adopted by the appellate courts which has had the most determinative effect on the impact of the ECHR.

The French reform adopted in June 2000 comprises some 142 articles, most of which modify parts of the CPP. Many of the provisions build upon the reforms of $1993,{ }^{41}$ seeking to make existing provisions more effective, such as the regulation of the garde à vue. Other provisions, such as the right of appeal from the cour d'assises and the establishment of the juge des libertés et de la détention, represent a long awaited but more radical departure from current arrangements.

\section{A WORD ABOUT LAWYERS}

Although not a separate head of reform there are numerous provisions scattered across different parts of the June 2000 project which impact directly upon lawyers either as the subjects of a criminal investigation or as representatives of the accused. Lawyers are allowed earlier access to their clients in police custody (Art 63-4) and a letter from the accused to the lawyer is now accepted as evidence that she has been instructed, rather than the more formal procedure of requiring this to be done through the juge d'instruction ${ }^{42}$ before being recognised as acting for the accused (Art 115). Lawyers will also be trusted to question witnesses directly, rather than through the trial judge (Arts $245,312,408)$. When themselves the subject of a criminal enquiry, their professional representative, the bâtonnier, may now challenge the seizure of documents from the lawyer's office (Art 56-1) and the juge d'instruction may no longer make it a condition of bail that the lawyer cease her professional activities (Art 138). These changes appear at different points in the reform project, the result of a wider trend to strengthen the position of the suspect and to treat all accused persons equally. But looking at them collectively, the

the defendant (of previous good character and showing no 'predisposition' to commit the offence of supplying drugs) was deprived of a fair trial because of his entrapment by police officers. The jurisprudence around the right to silence has allowed a wide margin of appreciation. A breach will be found only if some penalty attaches to the failure to speak (see Saunders v UK (1997) 23 EHRR 313). Anything less will not necessarily be condemned-see Murray (John) v UK (1996) 22 EHRR 29; Salabiaku v France (1988) 13 EHRR 379.

40 Section 78 PACE allows the trial judge a discretion to exclude evidence which, in all the circumstances, it considers it would be unfair to admit.

41 For a discussion of the 1993 reforms see J Hodgson and G Rich (1993) 'A Criminal Defence for the French?' New Law Journal (143), 414; H Trouille (1994) 'A Look at French Criminal Procedure', Criminal Law Review, 735-44.

42 The juge d'instruction is responsible for the investigation of the more serious and complex cases. More than 60,000 people each year are mis en examen, that is, investigated through the process of instruction, according to the Justice Minister in her speech to the Sénat, 15 June 1999. 
picture emerges of lawyers as having been little trusted to participate in the criminal process and having been poorly treated as accused persons themselves. ${ }^{43}$ As many parts of the new reform have serious implications for the role of the defence lawyer, it is worth pausing to reflect upon her place within French criminal procedure.

The French defence lawyer is something of an outsider in the criminal process. Whilst the procureur, juge d'instruction and trial judges enjoy the common status and collegiality of being magistrats, the defence lawyer is an avocat. This has a significance beyond the difference in the formal training process. It informs the legal culture and expectations of actors within the criminal process. Whilst the magistrat enjoys an elevated status as being entrusted with the administration of the law, engaged in a search for the truth in the public interest, the defence lawyer, in contrast, is seen as acting solely in the interests of the accused, for money. ${ }^{44}$ Within the French model of judicially supervised investigations, the role of the defence lawyer in the pre-trial process is very much subsidiary to that of the magistrat overseeing the enquiry. The avocat is there to ensure that procedures are respected rather than to participate in the process. It is for this reason that the relatively modest reforms of 1993, allowing lawyers access to suspects held in police custody, attracted much criticism: the introduction of the avocat was seen as undermining the role of the procureur in supervising the investigation. Making room for a partisan defence representative, even for 30 minutes, was considered an unwelcome intrusion and one which would lead to inequalities depending on the resources of the suspect to hire a lawyer. In short, the defence lawyer, as an outsider, is less trusted than fellow magistrats. However, the success of this most recent reform programme depends in part upon the willingness of the defence lawyer to play a greater role in the process. And in turn what is interesting about these reforms to the external observer, is that all of the measures which touch upon the role of the defence lawyer and the status of the avocat, seem to imply a greater degree of trust in her professional integrity.

Despite the generally low esteem in which lawyers have been held (in comparison to magistrats), they will be increasingly implicated in the criminal process as a result of these reforms, which in turn, will impact upon their work profile. If avocats in general enjoy a lower status than magistrats, this is especially so of the criminal lawyer. ${ }^{45}$ French criminal lawyers are characterised by

43 For an account of the rise of the profession between the thirteenth and fifteenth centuries, followed by the loss of status from the sixteenth century when a large status gap opened up between avocats and magistrats, see L Karpik, French Lawyers: A Study in Collective Action 1274-1994 (trans Nora Scott) (Oxford: Clarendon Press, 1999), ch 1.

44 As one juge d'instruction told me: 'The lawyer, he works as a liar, to see how far he can distort the law.' For further discussion of the importance of these contrasting legal cultures and professional ideologies, see Hodgson (above n 10).

45 This is true even of the way in which they are regarded within the profession. Of fourteen fields of law which Karpik (above n 43) uses for his analysis (based upon questioning lawyers), 
Karpik (1999) as typically young solo practitioners or associates with an unstable clientele. Unsurprisingly, they receive lower incomes than colleagues practising in other fields of law, as many of their clients are legally aided. ${ }^{46}$ Their work is more court than office based and much of it is regarded as being routine and repetitive, rather than technical, leading to some standardisation of practices in order to keep down costs and to attract more clients. The dispersed, itinerant nature of the criminal lawyer's work, driven by the demands of the court timetable rather than her own, means that 'work is experienced as an alternation between idle and busy time' and the lawyer must put in long hours if time is to be found for the analysis of documents and case preparation which is so vital in a process focused more on the construction of the dossier than on the trial. ${ }^{47}$ Recent reforms are likely to add to these pressures, imposing another externally driven timetable. The traitement en temps réel ${ }^{48}$ procedure depends upon the availability of lawyers to appear in court at short notice and the avocat will now be called upon to attend the garde à vue immediately, rather than after 20 hours. Whilst some suspects and defendants are repeat players who will already have their own lawyer, many will use the avocat commis d'office, the duty lawyer. Duty rotas are organised locally and tend to be staffed by young and inexperienced lawyers as part of their apprenticeship. ${ }^{49}$ Typically, the duty avocat will collect the dossiers for the afternoon's cases in the morning and have only a few hours in which to see all her clients and to prepare her courtroom pleadings. Rather like police station advice in Britain, ${ }^{50}$ this is potentially complex work, but it is often carried out by those lowest in the firm's hierarchy because it is unattractive and poorly paid. Yet, it is these same young and inexperienced people whose representation of accused persons in many instances, will form a crucial part of the rights and guarantees put in place by these reforms. Even within the adversarial-

crime ranked 12th in terms of prestige ( $\mathrm{p}$ 198). This is also the position in the UK, where criminal lawyers enjoy a relatively low status within the profession.

46 A typical case before the tribunal correctionnel will attract a fee of 700FF ( 100$)$, around $£ 70$. See Le Monde 17 May 2000.

47 Karpik (above n 43), 214. 'The typical solo practitioner, after pleading in two or three courts which are not necessarily in the same locale, after spending time at the palais taking care of the numerous details without which a case tends to bog down, after having visited clients in prison, having received clients in the office, no longer has enough time to analyse the case documents, to write up his pleadings, to prepare the advice and legal documents, without extending the limits of the ordinary working day: he or she must find the additional time early in the morning, late at night or on the weekends' (Karpik (above n 43), 215). The description of the lawyer's day is strikingly similar to those reported in research in England and Wales. See M McConville, J Hodgson, L Bridges, and A Pavlovic, Standing Accused: The Organisation and Practices of Criminal Defence Lawyers in Britain (Oxford: Clarendon Press, 1994), at, eg, 22-4.

48 Under this procedure, a permanent duty section is established and the procureur endeavours to make a decision whether or not to charge by the end of the police detention and investigation, rather than prolonging the enquiry and issuing further instructions by post.

49 D Cohen (1992) 'Le droit de l'assistance effective d'un avocat de la défense', Revue internationale de droit pénal, 63, 729-54.

50 See M McConville and J Hodgson, Custodial Legal Advice and the Right to Silence (London: HMSO, 1993) and McConville et al (above $\mathrm{n} 47$ ). 
styled process of England and Wales, lawyers failed to seize the opportunity which was presented by the suspect's right to custodial legal advice under section 58 Police and Criminal Evidence Act 1984 (PACE). Given the greater legal cultural shift required in France as a more inquisitorial process, it will be interesting to observe the impact of improved access to suspects held in police custody

\section{THE PRESUMPTION OF INNOCENCE—THE CARDINAL PRINCIPLE}

The presumption of innocence has long been considered a part of the French criminal process, from the importance of conducting a thorough enquiry at the pre-trial stage to the burden of proof at trial and the general incorporation of ECHR principles. As a more inquisitorially based process, much faith has been placed in the juge in charge of investigating the case, with a relatively diminished role being cast for the defence lawyer. And indeed, any juge d'instruction or procureur would describe their role in terms of the protection of defence rights as well as the investigation of the offence. ${ }^{51}$ Yet, the ways in which judicial supervision is played out and in particular, the dependence of the juge d'instruction or the procureur upon investigating officers, mean that in practice the police continue to dominate the enquiry. The absence of many basic safeguards such as immediate access to legal advice when detained in police custody, or the right of suspects to know why they are being held, was further symptomatic of a process which made inadequate provision for the translation of the presumption of innocence into the realities of criminal procedure. Many of the changes in June 2000 address this and the presumption of innocence is now described as a cardinal principle which should be respected at all stages of the criminal process and from which other principles follow. ${ }^{52}$ To make this more explicit, a new preliminary article is inserted at the start of the CPP setting out the fundamental tenets governing criminal procedure. ${ }^{53}$ This is considered necessary to try and regain public confidence in the judicial system and in its aspirations. The utility of this broad and general statement, however, will depend upon the willingness of the courts to adopt it as a guide to interpretation. ${ }^{54}$ The new preliminary article states that criminal procedure

\footnotetext{
51 This was described by the recent Truche Commission (P Truche, Rapport de la commission de réflexion sur la Justice (Paris: La documentation Française, 1997) as follows: 'It is for the parquet and the juge d'instruction to gather the evidence of any offence against the criminal law without presuming guilt. They are concerned to investigate both that which inculpates and that which exonerates, giving the suspect the benefit of any doubt. In doing this, they must respect legal procedures', at 60.

52 See the first few paragraphs of the Ministry of Justice's 'Exposé des motifs du projet de loi renforçant la protection de la présomption d'innocence et les droits des victimes.'

${ }^{53}$ Compare the ten fundamental principles which the Delmas-Marty Commission, 1991 (above n 24), 113-24 proposed should appear at the start of the CPP.

54 J Pradel (2001) 'Les personnes suspectes ou poursuivies après la loi du 15 juin 2000: Evolution ou révolution?' Dalloz (Doctrine) (13), 1039-47, notes that both Belgium and Canada rejected the idea of adopting a preliminary article setting out general principles.
} 
must be fair, allow issues to be debated by all sides and maintain a balance between the rights of the parties. There must be a clear separation between the investigation and prosecution and those responsible for trying the case. There should be equal treatment of accused persons and the judiciary are also responsible for protecting the rights of the victim. Those suspected of, or prosecuted for, committing offences are presumed innocent as their guilt has not been established. They are entitled to know the nature of the charges against them and to have a defence lawyer. Any restrictions on a person's liberty must be determined by judicial authority and be strictly necessary, in proportion to the gravity of the offence and not infringe the dignity of that person. The decision whether or not to pursue charges should be made within a reasonable time. All convicted persons have the right to have their conviction reviewed by another court.

After this preliminary article, there follow a host of changes concerning different stages of the criminal process which seek to put into effect these guiding principles. Some came into force immediately, some in January 2001 and some in June 2001.55 An exhaustive account of the reforms cannot be provided here, but some of the salient provisions will be examined.

\section{PROTECTING THE INTERESTS OF THE VICTIM}

The victim of a criminal offence has a greater role to play in the French process of criminal justice than is the case in England and Wales. She may constitute herself as partie civile which makes her a party to the proceedings and enables her to claim compensation before the criminal court. During the pre-trial enquiry, she enjoys the same rights of participation as the suspect: she may request that the juge d'instruction carry out particular investigations and through her lawyer, she has access to the case dossier. Where no prosecution has been brought, she may initiate proceedings directly before the court, or, in more serious cases or where the suspect is unknown, she may bring her case to the juge d'instruction. As well as the individual victim of the crime, a range of organisations representing particular interests may constitute themselves as partie civile and participate in the process as well as claim compensation from the convicted defendant. These include organisations which combat race or sex discrimination, child abuse, sexual violence, and prostitution and those which protect interests such as hunting and the environment.

The current reform seeks to strengthen these provisions and the Justice Minister described it as ensuring that victims would be better received, better heard, better protected, and better compensated by the criminal process. ${ }^{56}$ The provisions are designed to enhance the status of the victim as a party to the investigation and trial by providing greater opportunities for her to participate

\footnotetext{
2003.

55 Exceptionally some, relating to custody conditions, are scheduled to come into force in June

6 In her address to the Sénat 30 May 2000.
} 
in the process. This begins at the point of reporting the offence. Even where they have no jurisdiction to pursue the offence reported, the police must now take a statement from the victim and pass it on to those who are competent to deal with the matter (Art 15-3). The victim should also be informed of her right to seek compensation and the availability of victim support agencies (Arts 53-1; 75). At the start of instruction the victim must be told that she has the right to constitute herself as a partie civile (Art 80-3) and she must be kept informed of the progress of the investigation every 6 months (Art 175-3). The procedure whereby the victim may claim damages in the criminal court is simplified, allowing her to post or fax her claim and no longer requiring her to appear before the court in person (Art 420-1). The harm for which she may be compensated is also more broadly defined: her psychological as well as material state will now be considered in making any award of damages (Art 706-14). Where an information has been opened, the juge d'instruction may investigate the personality of the victim (as well as the accused) in order to assess the harm caused to her by the offence (Art 81-1). The list of those who may constitute themselves as the partie civile has been expanded to include organisations which fight against homophobia (Art 2-6) and against sects (Art 2-17), as well as those representing people who have suffered accidents at work and work related illness (Art 2-18). There is also provision for the recognition of (the very French) organisations representing mayors (Art 2-19). In the cour d'assises, the partie civile may appeal against the decision concerning damages awarded her, even if the defendant has not initiated the appeal process (Art 380-2; 380-5).

\section{THE MEDIA ${ }^{57}$}

The different ways in which material has been publicised by the various parties to a case demonstrates the historical tension that exists between politicians, legal actors, and the media, in defining what amounts to legitimate public information. While Article 11 CPP binds all those participating in a case to secrecy, juges d'instruction in particular have used the press to manipulate the presentation of information during investigations and to ensure that politically sensitive cases are taken to trial. This was seen clearly in two high profile cases: the allegations of match rigging against the government minister Bernard Tapie; and the scandal of AIDS contaminated blood which, compared to any other country in Europe, resulted in between four and thirteen times more people in France becoming contaminated with the AIDS virus after undergoing a blood transfusion. ${ }^{58}$ The press, in turn, has actively monitored

\footnotetext{
57 For a broad discussion of the role of the media in French criminal proceedings, see Bell (above n 10), 117-25

58 For a detailed discussion of the AIDS-contaminated blood case, which involved accusations against three former government ministers for their failure to supervise adequately the health service, see C Elliot and C Vernon, French Legal System (Harlow: Longman, 2000), 101-10.
} 
the conduct of investigations and lawyers have also used the media to construct publicly an alternative account of their client's situation. ${ }^{59}$ This tension in defining the legitimate use of the media continued in the contrasting reform demands of the press and of the government. In their evidence to the Truche Commission, the press argued for greater transparency in the investigation process, with an obligation upon the judicial authorities to provide information. The reforms proposed and then legislated by government, on the other hand, concerned the imposition of greater restrictions on the ways in which the media could report cases. ${ }^{60}$

Measures to strengthen the presumption of innocence and those for the protection of the rights of victims, both include restrictions on the media reporting of cases. Preserving the anonymity of juvenile suspects (Art $39 \mathrm{Loi}$ 1881) or the victims of sexual offences (Art 35 Loi 1881) is relatively straightforward, but the reforms go further than this. It is now an offence to publish images of the circumstances of an offence, without the victim's consent, if to do so would seriously damage that person's dignity (Art 35, Loi 1881). The media's treatment of the accused also comes under the spotlight. The judicial authorities are obliged to take measures to avoid pictures being taken of people chained or handcuffed (Art 803) and it is an offence to publish such pictures without a person's consent if it seriously attacks that person's dignity (Art 35 Loi 1881). It is also an offence to take a public poll on the guilt of an accused person. These provisions were the subject of heated debate. ${ }^{61}$ Media representatives claimed that such restrictions attacked the freedom of the press, but the then Minister of Justice, Elisabeth Guigou, maintained that to allow such images undermined the presumption of innocence and served only commercial interests, rather than those of the legitimate provision of public information.

\section{REGULATING THE INVESTIGATION}

There are a number provisions designed to tighten up the regulation of the pretrial investigation. Just as in England and Wales, the sheer volume of cases and the lengthy delays experienced by victims and defendants are the cause of much concern. In line with other measures to reduce delay within the criminal

\footnotetext{
59 See, eg, the reports in Le Monde (21 July 2000; 25 July 2000) of the juge d'instruction's interview with Jean Tiberi, the Mayor of Paris who was accused of corruption in misusing the influence of his public office.

60 The acquittal in November 2001, of the former minister Dominique Strauss-Kahn, has again highlighted the tension between the right to know and greater transparency on the one hand and the presumption of innocence on the other. Many claim that being named as a suspect instantly stigmatises that person-in this case, causing the minister to resign from his post.

61 The original proposal (which would have allowed the parquet to prosecute offenders in the media independently of the view of the victim) was modified in October 1999, after representations from the press. Only images taken without the person's consent and about which she has brought a complaint may be the subject of a prosecution.
} 
process, such as the rapid trial procedure of comparution immédiate ${ }^{62}$ and the more immediate decision-making required by the procureur under the temps réel procedure, procureurs are required to set a timetable within which enquiries should be carried out and the police must report within 6 months on enquiries made on their own initiative (Art 75-1). As soon as a suspect is identified, the procureur must be informed (Art 75-2). In this way, investigations can be progressed more quickly, minimising the need to restrict the liberty of those involved in the enquiry. If a suspect has been released after detention in garde à vue, after a period of 6 months she may require the procureur de la République to review the progress of the investigation authorising either its closure or referring it to the JLD who will decide whether or not the enquiry can be pursued (Arts 63-1; 77-2; 77-3).

As with ordinary investigations, where an information has been opened, the juge d'instruction must set down a provisional timetable (Arts 89-1; 116). If this is exceeded, or if no investigations have taken place for a 4-month period, the parties can challenge the juge d'instruction either to send the case for trial or to close the enquiry (Art 175-1). The length of the instruction should take account of the necessity of balancing the complexity of the investigation needed to discover the truth, against the rights of the defence. Any enquiry which lasts for 2 years must be justified on these grounds before the president of the chambre d'instruction (Art 175-2). The orientation of the instruction enquiry is also clarified. The professional training of the juge d'instruction emphasises her role in investigating the evidence both for and against the suspect, à charge et à décharge. This is now made more explicit and written into Article 81.

The system of police discipline has also been modified and came into immediate effect. Police officers accused of misconduct whilst carrying out their judicial functions will now be investigated by a judicial inspectorate rather than one under their own hierarchy. This may be ordered by the Minister of Justice and so conducted by a magistrat (Art 15-2). Decisions of the chambre d'accusation stripping an officer of his status as police judiciaire thereby preventing her from conducting criminal investigations will now take immediate effect (Art 227).

\section{DETENTION IN POLICE CUSTODY: THE GARDE À VUE}

The legislation enacted in 1993 sought to regulate the police custody period, garde à vue (GAV), through a combination of judicial supervision, record keeping, and the provision of legal and medical assistance to those detained.

62 Broadly speaking, this allows the trial to take place the same day as charges are formally brought against an accused, if the maximum sentence for the offence is between 1 and 7 years imprisonment and the procureur judges that the case is ready for immediate trial (Art 395 CPP). Current proposals set out in July 2002 (Lopsi: Loi d'orientation et de programmation pour la sécurité intérieure) would extend this procedure to offences with a maximum sentence of 10 years' imprisonment. 
Most of the June 2000 changes relating to the GAV sought initially to strengthen and make more effective these existing provisions, but, under pressure from the police and gendarmes, there has been some back-pedalling. The 'petite loi' passed at the start of 2002 is described as legislation 'complementing' that of June 2000, though it will be seen by many as a retrograde step.

\section{A. Supervising the Suspect's Detention}

Suspects placed in police custody are done so on the initial authority of a police officer who must then inform the procureur who is responsible for overseeing the detention period ${ }^{63}$ and then deciding whether or not to charge, release, refer the suspect to the juge d'instruction for further investigation or instigate some alternative measure to prosecution. ${ }^{64}$ The 1993 legislation required officers to inform the procureur of the detention of a suspect 'as soon as is practicable' (Arts 63, 77; Art 154 during instruction), but this was amended in June 2000 so that the information must be communicated at the start of the GAV. In the context of already stretched resources, police, and magistrats reported the strain that this placed upon them: officers had to wait up to one-and-a-half hours to get through on the telephone to the parquet ${ }^{65}$ and in small areas with only one or two procureurs, they were obliged to take it in turns be on duty 24 hours a day, leaving little time for rest. ${ }^{66}$ Initially, the Justice Minister insisted that the reform was a success and that once people were accustomed to the new procedures and the extra resources had taken effect, things would settle down. However, after reports evaluating the implementation of the reform project, the government proposed a number of amendments which allowed the police more flexibility during the GAV period. Among these is the less onerous requirement that the procureur need now be informed, not at the start of GAV, but 'as quickly as possible'.

The purpose of contacting the procureur in this way is to ensure that the GAV is properly conducted. The Commission Nationale Consultative des Droits de l'Homme (CNCDH), in their consideration of the February 2002 legislation, ${ }^{67}$ underlined the central importance of the procureur's involvement for the protection of the rights of the suspect. However, just as in England and Wales, where the custody officer systematically authorises the detention of suspects, ${ }^{68}$ in France too, authorisation is granted routinely unless

\footnotetext{
63 More than 300,000 people are placed in police detention, garde à vue, each year according to the Justice Minister in her speech to the Sénat, 15 June 1999.

64 See $n 5$ above.

66 See Le Figaro 9 Mar 2001.

$67 \mathrm{CNCDH}$ Avis sur la proposition de loi complétant la loi du 15 juin 2000 renforçant la protection de la présomption d'innocence et les droits des victimes, 24 Jan 2002.

$68 \mathrm{C}$ Phillips and D Brown, Entry in to the criminal justice system: a survey of police arrests and their outcomes. Home Office Research Study No 185 (London: Home Office, 1998), found only one case out of a sample of 4,246 where detention was refused. See also M Maguire and C Norris, The conduct and supervision of criminal investigations. RCCJ Study No 5. (London:
} 
there is clearly no legal basis for arrest and detention. ${ }^{69}$ Indeed, the very nature of police-procureur communications in many instances, demonstrates that there is an assumption that detention will not be refused: the transmission of information by the police to the procureur is characterised not as a request for authority or direction, but as a simple communication of information, not necessarily requiring any response. ${ }^{70}$ In virtually all instances in practice, this information is given over the telephone or by fax and the whole of the GAV period is supervised in this way. ${ }^{71}$ Although the guidance notes accompanying Article 41 anticipate that supervision of the GAV will include visits to the police station, ${ }^{72}$ attendance is virtually unheard of in most areas. Visits which do take place are designed to strengthen working relationships with the police, rather than to function as a form of check or inspection. ${ }^{73}$ The new law initially required the procureur to visit the police station at least once every 3 months and to keep a record of these visits (Art 41$),{ }^{74}$ but this was subsequently amended in February 2002 to once a year. Given the culture in which all attendances are agreed beforehand and unannounced visits are frowned upon, the impact that this requirement will have is uncertain. Concerns about the conduct of the GAV have centred not upon the treatment of those detained,

HMSO, 1993), who attribute the weakness in police supervision to the fact that supervising officers are subject to the same performance pressures as fellow officers and do not wish to be seen to undermine the work of their colleagues, the arresting officers.

69 The most recent circular produced by the Ministry of Justice emphasises the originating power of the OPJ to place a person in GAV. The role of the procureur is in judicially supervising the GAV period and not in validating the decision of the OPJ. Given the procureur's duty to supervise the conduct of the GAV and to direct the police in the investigation and collection of evidence; and given that she alone may authorise the release or further detention of the suspect, this is arguably an unjustifiable distinction to draw. If an OPJ has placed a person in GAV without proper grounds, the procureur should order the suspect's release. If she does not, she is confirming the decision of the OPJ to detain. This is surely part of the rationale of the safeguard for requiring the procureur to be informed of any detention.

70 The most common reason for any discussion between the police and procureur is not to dispute detention, but to clarify legal procedure and form and to discuss avenues of enquiry. In one area, even this was precluded as all initial detention information was sent by fax and remained unread until the close of detention. See J Hodgson (2002) 'Hierarchy, Bureaucracy and Ideology in French Criminal Justice: Some Empirical Observations', Journal of Law and Society 29(2), 227 at p 243.

71 The most recent Ministry of Justice circular (10 Jan 2002) makes it clear that the dossier need only contain a reference to the fact that the procureur was informed by fax. The fax itself need not be appended. In this way, the dossier will not reveal the terms in which the procureur was informed, the very information on which any decision by her will be made.

72 The circulaire générale says, 'As in the past, visiting the garde à vue will allow the procureur to ensure that it is properly conducted and that the procedures are respected.'

73 One procureur explained the danger of a more surveillance based approach: 'There used to be a woman in the permanence who did go down to the police station and it caused a terrible rumpus. The police were furious that she just turned up. You have to be careful when you go down-so that the police don't think it's because you're suspicious of them', Hodgson (above n 10), 351 .

74 The Collomp report (above, n 21), para 1.4.2, charged with evaluating the success of the reform, noted that of the ten parquets inspected, only four had complied fully with the requirement to visit each police station every 3 months. Three had made no visits and three had made only some. Of particular concern was the number of stations to be visited and the distances between them 
but upon the material conditions of their detention ${ }^{75}$ and it is likely that this will be the focus of attention in undertaking such visits. ${ }^{76}$

Although regulation of the GAV now includes a number of PACE-like provisions, the ideal of judicial supervision remains at the heart of the French pre-trial process and in over 92 per cent of cases this is carried out by the procureur. However, much of the procureur's supervision of the GAV is carried out retrospectively, through scrutiny of the official records of procedures and evidence gathered. Given that interrogations are not tape recorded and neither magistrats nor lawyers are present, the procureur is wholly dependent upon the dossier of evidence assembled by the police. ${ }^{77}$ Historically, the questioning of both suspects and witnesses has been recorded in the form of a simple signed statement. At the discretion of the interrogating officer or the juge d'instruction, some responses were noted down verbatim, prefixed with 'S.I.' (sur interpellation, under questioning). In most instances, this has the effect that several hours of interrogation will yield a statement of only a few pages, with no sense of how the information has emerged. Procureurs are generally unconcerned at the length of interrogations unless they are excessive and threaten the credibility of the evidence obtained. This discretionary practice is repealed and the questions posed must now be noted down in the interrogation of suspects and witnesses, including the victim or partie civile (Art 429). ${ }^{78}$ Whilst it is hoped that this will make more transparent the construction

75 The circular (4 Dec 2000, para 1.3.1) accompanying the June 2000 legislation anticipates that visits will be directed towards ensuring the adequacy of the material conditions of the GAV, rather than the treatment of individual suspects.

76 This is not to deny the importance of monitoring material conditions - as highlighted by the most recent report of the European Committee for the Prevention of Torture and Inhuman or Degrading Treatment or Punishment (2001) which criticised the meagre progress made by France over the last 8 years in this respect. Poor conditions of detention were highlighted in the reports following both the 1991 and 1996 visits. Rapport au Gouvernement de la République française relatif à la visite en France effectuée par le Comité européen pour la prévention de la torture et des peines ou traitements inhumains ou dégradants (CPT) du 14 au 26 mai 2000 (2001), para 22. The committee also commented that it hoped procureurs would make full use of their powers to visit police stations (para 40). The government's response (Réponse du Gouvernement de la République française au rapport du Comité européen pour la prévention de la torture et des peines ou traitements inhumains ou dégradants $(C P T)$ relatif à sa visite effectuée en France du 14 au 26 mai 2000 (2001)) was that visits would ensure that the GAV is conducted according to the provisions of the law. Given the rarity of such visits, this is unlikely.

77 This is significant, as the process of interrogation and detention remains shielded from close scrutiny. LH Leigh and L Zedner, A Report on the Administration of Criminal Justice in the Pre-Trial phase in France and Germany. RCCJ Study No 1 (London: HMSO, 1992), found that interrogation could take place for oppressive lengths of time in order to 'break' the suspectalthough their research was conducted prior to the 1993 reforms. The European Committee for the Prevention of Torture and Inhuman or Degrading Treatment or Punishment, 2001 (above n 76) again suggested the clear need for a code of conduct to guide police in interrogating practice and standards (para 37). This is the third time that this point has been made (it was raised following the 1991 and 1996 visits) but the Government response (2001, above n 76) denies that such a code is necessary.

78 The revision does not go as far as to say that every question and answer must be noted down contemporaneously (as was the case in England and Wales before tape recording was fully introduced) and so the way in which new practices will develop is unclear. 
of witness statements, including that of the suspect herself, this is in no way guaranteed. Much will depend upon the ability (and desire) of the police to change their working practices, as well as the willingness of the parquet to uphold the new requirement.

It is instructive to consider here the influence of different occupational cultures upon the effectiveness of legislative change such as that under PACE, requiring that all police-suspect interviews in England and Wales be tape recorded. Defence lawyers welcomed the change, hopeful that it would benefit their clients by portraying some of the harsher realities of police practice. The police initially opposed tape recording (possibly for the same reason), but officers soon came to realise that it served their interests in protecting them from false allegations of improper questioning or of violence, whilst at the same time providing an indisputable account of the interrogation process. Defendants, for their part however, did not reap the benefits they had hoped for. First, recordings were only rarely listened to by either the court or by defence lawyers who preferred to rely on the summary of interview prepared by the police. ${ }^{79}$ These 'summaries' often omitted information helpful to the defence, emphasising only the parts which appeared to support the prosecution case. ${ }^{80}$ In this way, inaccuracies and misrepresentations detrimental to the defence case were not identified and in some cases, clearly oppressive questioning went unchallenged. ${ }^{81}$ Secondly, whilst the tape recording faithfully reproduces what was said in interrogation, it fails to provide any information about the much greater length of time which the suspect spends in custody outside the interrogation room. In particular, the effect of questioning in the car on the way to the station or during cell visits by officers, remains invisible. ${ }^{82}$ The tape recording appears to provide a complete account of the interrogation, but in fact, it may be the product of a process begun much earlier. The requirement for a fuller account of the interrogation process in France is to be welcomed, but the working practices of the police (currently invisible to outside scrutiny) and the procureur will determine the extent to which this legislation effects any real change.

79 McConville et al (above $\mathrm{n}$ 47) found that defence lawyers rarely listened to tapes. Judges reported listening to tapes in only 11 per cent of contested Crown Court cases (M Zander and P Henderson, The Crown Court Study. RCCJ Study No 19 (London: HMSO, 1993), ch 3) and the figures are likely to be much lower in the magistrates' court. Officers in France complain that nobody watches the recordings of interrogations of juveniles. See Dray (above n 21) s 9.

${ }^{80}$ See J Baldwin, Preparing the Record of Taped Interview. RCCJ Study No 2 (London: HMSO, 1993).

81 In the case of Stephen Miller (one of the 'Cardiff Three' accused of the murder of a Cardiff prostitute) the police interrogation continued despite more than 300 denials on his part. Notably, his solicitor was present throughout and was described as 'being gravely at fault for sitting passively through this travesty of a [police] interview.' $R v$ Paris, Abdullahi and Miller (1993) 97 Cr App R 99.

82 See S Moston and GM Stephenson, The Questioning and Interviewing of Suspects Outside the Police Station. RCCJ Study No 22 (London: HMSO, 1993). There is a strong incentive for such unofficial questioning: the authors found that 74.5 per cent of such cases resulted in some form of admission, compared to 58.8 per cent of official interviews ( $\mathrm{p} 34$ ). 
In addition to supervision by the procureur, the 1993 legislation introduced a number of other safeguards for the regulation of the GAV in terms similar to those contained in PACE. It became a requirement that custody records be kept and suspects were allowed to contact a friend or relative and to see a doctor and a lawyer. Under the June reform, the suspect's family were not simply to 'be informed' of her detention, but this was to be done 'without delay' (Art 63-2) and the detention record must note meal times as well as the existing requirement to detail rest periods and interrogation times (Art 64). Under the February 2002 legislation, a delay of up to 3 hours is now permitted in informing the suspect of her right to see a doctor, or to inform someone of her detention. This has been criticised by the CNCDH as likely to introduce a norm of a 3-hour delay, which in many instances will be excessive. ${ }^{83}$ These documents recording when the suspect has been given her rights and when she has been interrogated, are crucial, representing the official account of the suspect's time in custody. Their value in England and Wales, however, has been questioned on a number of grounds. They are compiled by a police officer; suspects are often required to sign 'here, here and here' without proper explanation of the consequences; and whilst the custody record may reveal information helpful to the defence, in many instances, it is primarily a construction, the purpose of which is to demonstrate compliance with PACE ${ }^{84}$ There is no reason to suppose that the French experience will be markedly different. ${ }^{85}$

\section{B. The Role of the Defence Lawyer}

However, it is the presence of the defence lawyer during the GAV period which has generated the most debate, much of it echoing that surrounding the introduction of custodial legal advice under PACE. ${ }^{86}$ The police in England and Wales were strongly opposed to the idea of allowing defence lawyers access to suspects held in custody, claiming that it would hamstring investigations and result in huge increases in the numbers of suspects remaining silent. The 1993 reform in France was modest by comparison, with lawyers allowed only a 30-minute consultation 20 hours after the start of detention and remaining prohibited from attending the police interrogation of their client. Yet, both police and magistrats, as well as many commentators, opposed the

\footnotetext{
83 Opinion on the proposed legislation 24 Jan 2002, above n 67

84 See eg D Dixon, K Bottomley, C Coleman, M Gill, and D Wall (1989) 'Reality and rules in the construction and regulation of police suspicion.' International Journal of the Sociology of Law, 17, 185 and M McConville, A Sanders, and R Leng, The Case for the Prosecution (London: Routledge, 1991), for early evaluations of the impact of PACE.

85 In the course of my own research I witnessed suspects signing blank forms to be filled out later as part of the custody record.

86 See J Hodgson and G Rich (1995) 'L'avocat et la garde à vue: experience anglaise et reflexions sur la situation actuelle en France', Revue de science criminelle et de droit pénal comparé (2), 319-29.
} 
reform, claiming that it introduced an unwelcome adversarial element into the procedure and in particular, fearing the disruptive effect that the presence of a defence lawyer might have. ${ }^{87}$ In both jurisdictions, these concerns proved to be misplaced and custodial legal advice has had little impact upon the conduct of the investigation, whilst at the same time serving to demonstrate at trial that the police detention period has been properly conducted. ${ }^{88}$ Despite being available to all and free at the point of delivery, less than one-third of suspects detained by the police in England and Wales receive custodial legal advice. ${ }^{89}$ Empirical research and a number of high-profile miscarriages of justice demonstrated that where suspects were seen, lawyers in England and Wales were not overly protective of their clients' rights, but rather, that they were insufficiently adversarial and frequently provided inadequate and incompetent advice. The Royal Commission on Criminal Justice, reporting in 1993, ${ }^{90}$ were concerned that this left the suspect poorly protected and their recommendations led to the establishment of an accreditation scheme, administered jointly by the Law Society and the Legal Services Commission, requiring police station advisers to demonstrate their competence (through examination and the submission of portfolios) before they will be paid for any custodial legal advice provided. ${ }^{91}$ The police, for their part, came to prefer the presence of a defence lawyer during interrogation and its effect in legitimating any confession evidence obtained. Thus, in contrast to the objections to the introduction of custodial legal advice and in particular, to claims that it would 'tip the balance' in favour of the suspect, additional measures have been required to compel lawyers to carry out their work with due diligence. ${ }^{92}$

87 See, eg, P Waquet (1991) 'Réflexions sur les rapports de la Commission Justice pénale et droits de l'homme', Revue de science criminelle et de droit pénal comparé, 3, 518-25; M Gendrel (1992) 'Garde à vue et droit de l'individu. La défense doit-elle commencer dans les locaux de gendarmerie ou de police?', Droit pénal (Mars), 1-3.

88 See further Dixon et al (above n 84) and McConville et al (above n 84) for an account of the effect of PACE upon investigations; McConville and Hodgson (above $\mathrm{n}$ 50) for an evaluation of custodial legal advice.

89 See, eg, T Bucke and D Brown, In police custody: police powers and suspects' rights under the revised PACE codes of practice. Research Study No 174 (London: Home Office, 1997). Whilst the police were found initially to adopt a number of ploys to dissuade suspects from requesting legal advice (such as failing to mention that it was free, or most effectively, warning that it would increase the length of time spent in custody) changes in the Codes of Practice sought to minimise this. The low take-up rate appears to be a result of a low request rate, rather than any refusal on the part of the police to allow access.

90 Royal Commission on Criminal Justice, Chaired by Viscount Runciman of Doxford (1993) Cmnd 2263. London: HMSO.

91 See L Bridges and J Hodgson (1995) 'Improving Custodial Legal Advice', Criminal Law Review, 95 and L Bridges and S Choongh, Improving Police Station Legal Advice: The Impact of the Accreditation Scheme for Police Station Legal Advisers (The Law Society and Legal Aid Board, 1998), for evaluations of the scheme.

92 In addition, it should be noted that although introduced initially as a necessary counterbalance to the increased police powers introduced under PACE, the presence of a defence lawyer during police interrogation has been used over and again to justify further inroads into the suspect's due process rights - most notably in the curtailment of the right to silence under the Criminal Justice and Public Order Act in 1994. 
In France too, the police and magistrats have acclimatised to the changes of 1993, recognising that it posed little threat and in many instances served their interests: little could be achieved after 20 hours of detention, but the provision of defence rights at this stage served to reinforce and legitimate the procedure. Under the 2000 reform, defence lawyers may now attend the suspect at the start of detention, ${ }^{93}$ rather than after 20 hours (Art 63-4) and the police must inform the adviser of the date and nature of the offence concerned, rather than simply the nature of the enquiry (Art 63-4). ${ }^{94}$ When questioned about this proposed reform in the course of my own empirical research, both police and magistrats were strongly opposed to the changes, rehearsing the same objections that were made in relation to the 1993 legislation. ${ }^{95}$ Once again, in practice, they have found that the reform makes little difference ${ }^{96}$ and in some instances, the earlier provision of custodial legal advice is of positive benefit. $^{97}$

\section{The Detention of Witnesses}

Other reforms represent a more radical break with the traditional inquisitorial roots of the process. Witnesses may no longer be held in GAV during any investigation. Holding a witness in custody against her will may serve 'the needs of the enquiry' - a frequent justifying criteria in French criminal procedure-but it is hardly compatible with a presumption of innocence. It was only

93 And again after 20 and then 36 hours, if detention is prolonged. The suspect is only told of her right at the start of detention and the official evaluation of the June 2000 reform (Collomp (above $\mathrm{n} 21$ )) notes that certain lawyers thought that suspects should be reminded of the right again after 20 hours of detention. Where the suspect is held in connection with organised crime, she will only be able to see her lawyer after 36 hours and in instances of drug trafficking and terrorism, after 72 hours. The European Committee for the Prevention of Torture and Inhuman or Degrading Treatment or Punishment (above n 76) was strongly critical of these exceptional provisions and recommended that all suspects be given immediate access to legal advice. The Government responded (above $\mathrm{n}$ 76) that access in such instances was delayed and not denied and that such provision was necessary in the public interest. (Cf Murray v UK (1996) 22 EHRR 29, where the European Court held that denying access to legal advice for 48 hours to a terrorist suspect was incompatible with the fair trial provisions of Art 6 ECHR. A similar decision was reached in Magee v UK (2000) HRCD 277. Both of these cases involved the Criminal Evidence (Northern Ireland) Order 1988 which allows the court to draw adverse inferences from silence, making legal advice arguably more important.)

94 Earlier access to a lawyer was the intention of the original 1993 project, but a change of government later that year prevented the second half of the reforms from coming into effect.

95 In my own questionnaire survey, 100 per cent of police and 84 per cent of procureurs opposed the change. Pradel (above n 54) remains sceptical of this new reform, arguing that it presents the risk of undermining the investigation if friends and accomplices are warned of a person's detention and subsequent searches prove unfruitful. This comment demonstrates a continuing suspicion of defence lawyers and their integrity.

96 No specific figures are provided, but the official evaluation report notes only a slight increase in the number of suspects attended by a defence lawyer. Collomp (above n 21), para 1.4.1

97 See, eg, Le Monde 19 June 2001. One officer told the reporter: 'I have also noticed that the arrival of the lawyer, straightaway, that releases the tension of really furious suspects who would sometimes take three or four hours to calm down. And for us, that is real progress.' 
in 1993 that this power was removed in enquêtes préliminaires and enquêtes de flagrance have now been brought into line (Arts 62, 63, 153, 154) ${ }^{98}$ The recently reported decrease in the number of people placed in GAV has been attributed largely to the removal of this power. ${ }^{99}$ However, whilst the government has not sought to reverse this reform, the most recent Ministry circular goes to some lengths to emphasise the powers to detain witnesses which the police continue to enjoy ${ }^{100}$ and the variety of ways in which a person might be considered a suspect for the purpose of detaining her in GAV. ${ }^{101}$ The grounds for suspicion outlined are arguably weaker than those which would be acceptable under PACE and the codes of practice. For example, a person behaving abnormally and in particular, who flees on the arrival of the police might be considered a suspect and detained. A person interviewed as a witness who refuses to answer questions may also be considered a suspect, raising serious issues about the rights of witnesses (against whom there is no suspicion of having committed an offence) to remain silent. The circular purports to remain faithful to Article 5 (1)(c) of the ECHR, which requires reasonable suspicion of having committed an offence before a person may be detained. However, it appears to have narrowed the definition of suspicion from des raisons plausibles de soupçonner to une raison plausible permettant de soupçonner, that is, from the plural to the singular. ${ }^{102}$ This has also occurred in the 'petite loi' of February 2002, where the grounds for detaining someone in GAV have been diluted from 'evidence giving rise to suspicion' to 'one or more reasons to suspect'. This change was not requested by the Dray report ${ }^{103}$ which preceded the legislation and the CNCDH opposed the modification as wholly unnecessary. ${ }^{104}$

\section{The Right to Silence}

A further major change is that those held by the police must now, for the first time, be told of the nature of the offence of which they are suspected and of their right to silence-if necessary through a sign language interpreter

98 The enquête flagrante is the investigation of the 85 per cent of offences which are classed as being flagrant. This is defined in Art $53 \mathrm{CPP}$ and, in general, refers to offences which are being, or have recently been committed. The distinction is important in determining the powers of the police and the length of time the suspect may be detained in custody.

99 See Le Monde, 19 June 2001

100 Witnesses may be retained for the time necessary to take a statement from them. This need not take place immediately upon their detention and a period of 4 hours in custody is considered acceptable, by analogy with the procedure relating to identity checks. In addition, if the witness will not come to the station voluntarily, force may be employed on the authority of the procureur.

101 Circular 10 Jan 2002-see esp para 1, 1.1, 1.2.

102 This is underlined in para 1.1 - 'There need exist only one single piece of evidence' against the person. The tentative nature of this evidence is also emphasised-it need not be enough to open an information, to prosecute or to convict.

103 Dray (above n 21). The report suggested a practical interpretation to guide officers, which was provided in the circular 10 Jan 2002

1042002 (above n 67). 
(Art 63-1). The impact of these obligations, however, is likely to be restricted by the manner of their implementation. The official Ministry of Justice circular which accompanies the legislation instructs officers that they should not remind the suspect of her right to silence at the start of interrogations. This is neither desirable nor legally required according to the document and to do so would be 'pointless' and an encouragement to the suspect to remain silent, which would be against her own interests. Nevertheless, the reform was widely opposed and it was feared that coupled with the earlier access of suspects to custodial legal advice, many more would exercise their right to silence and so hinder the investigation and the search for the truth. ${ }^{105}$ Unsurprisingly, just as was the case in England and Wales, these fears have not been realised and silence continues to be exercised only rarely. ${ }^{106}$ Despite this, the 'petite loi' has again intervened to modify the way in which the suspect is informed of her right to silence, mirroring the way in which the juge d'instruction provides this information to the mis en examen. The suspect will no longer be advised that she 'has the right not to respond to questions put', but that 'she has the choice to be silent, to respond to questions put to her or to make a statement'. Initial plans to introduce a warning that silence may harm the defence were dropped. ${ }^{107}$

These are vitally important reforms and given the constant references to ECHR standards in Parliamentary debates for over a decade now, it is amazing that suspects have not enjoyed these rights until now. Indeed, it is surprising that they do not perhaps go further and allow, for example, lawyers to be present during the interrogation of the suspect, rather than restricting the lawyer-client consultation to 30 minutes at the start of detention. ${ }^{108}$ This is particularly so given the different regime in place during the process of instruction, where lawyers are present during the questioning of the accused (which is meticulously typed up and agreed by the accused and her lawyer)

\footnotetext{
105 See also the cynical comments of Pradel (above n 54) who dismisses this aspect of the reform as having little effect: the right to silence already existed and seasoned criminals have always known this. He does not countenance the value this might have to the first time or innocent suspect.

106 See, eg, the report on the implementation of the 2000 reforms, Collomp (above $\mathrm{n} 21$ ), para 1.4.2; Le Monde, 19 June 2001. Interestingly, those who are silent are likely to be disciplined for their non-cooperation-see Le Monde 13 Feb 2001.

107 The CNCDH (above n 67) denounced the clause as placing pressure on the suspect, hindering the proper organisation of her defence and resting upon no legal basis.

108 For a more detailed discussion of the reluctant accommodation of the defence lawyer within French pre-trial criminal procedure, see J Hodgson (2002a) 'Constructing the pre-trial role of the defence in French criminal procedure: An adversarial outsider in an inquisitorial process?' International Journal of Evidence and Proof, 6(1) 1-16. The European Committee for the Prevention of Torture and Inhuman or Degrading Treatment or Punishment (above n 76) recommended that the defence lawyer be present during police interrogation of suspects (para 34). This was not responded to directly in the Government's response (above n 76). The Committee also recommended that all interrogations be tape-recorded (para 38), as did the Truche Commission (above $\mathrm{n}$ 51). The Government noted that videotaping would be considered, though 6 months later in January 2002, it announced that this has been ruled out for the moment.
} 
and have access to the dossier of evidence. As instruction takes place in less than 7 per cent of all investigations it is unsatisfactory that these basic safeguards are present in only a small minority of cases. The suspect is arguably far more vulnerable when in police custody, rather than before a magistrat, and so in greater need of safeguards such as lawyers and the proper recording of interrogations. Interestingly, this was the view of the Truche commission, who considered it essential that all interrogations be tape recorded (1997: 64). This view was not, however, shared by the government and the proposal was not taken up as part of the reform programme.

\section{E. Juveniles}

Juveniles enjoy slightly enhanced safeguards during their period of police detention, as well as a different investigation and trial process often involving the specialist juge des enfants. ${ }^{109}$ In contrast to adults, who were obliged to wait 20 hours under the 1993 reforms, juveniles were allowed access to a defence lawyer at the start of detention. It is again in the treatment of juveniles that the way is paved for more far-reaching changes in the treatment of those held in garde à vue. Taking effect in June 2001, the interrogation of juveniles must now be videotaped and this was to be monitored after one year with a view to the possibility of extending provision to all suspects. ${ }^{110}$ The Minister of Justice has already announced that there will be no proposal to videotape interrogations with adult suspects. This decision follows the Dray report which found only one instance where the recording was seen (not all courts being equipped with the necessary facilities) despite the additional work which the new requirement has generated. ${ }^{111}$ There is no equivalent provision, however, for juveniles, or other 'vulnerable' suspects to be attended by an appropriate adult, as there is in England and Wales.

\section{THE INSTRUCTION}

The juge d'instruction supervises the investigation of the most serious or complex offences, amounting to less than 7 per cent of all cases. Her involvement is triggered by the procureur opening an information, which is mandatory for crimes, the most serious offences and at the discretion of the procureur for délits and contraventions (Art 79). The juge d'instruction has

109 See C Blatier (1999) 'Juvenile delinquents in France: Main Components of the Evolution of Justice for Minors' British Journal of Criminology, 39 (2) 240-52, for an account of the legal regime governing juveniles in France. But note also the repressive measures proposed by the new government in July 2002 (above n 62).

110 Art 4 of ordonnance number $45-174$ of 2 Feb 1945 concerning juvenile crime. The video will only be viewed if the content of the statement is contested.

111 Videotaping the interrogation has not relieved officers of the requirement to make a written record. Dray reports that officers felt that they were working to no purpose, given the additional effort required to make a recording which nobody will see. Dray (above n 21) s 9. 
wide powers to undertake any lawful investigations which she considers useful in the search for the truth (Art 81), which may include telephone taps or staging a confrontation between witnesses and the accused, as well as interviewing witnesses and gathering expert evidence. These acts may be done on the juge's own initiative, or at the request of the procureur, the accused or the victim (Art 82). Other than the questioning of the accused (who is known as the mis en examen at this stage) and preparation of the report on her background (the enquête de personnalité ) investigations may be formally delegated to police officers through the commission rogatoire (Art 151), granting them the same powers as the juge d'instruction herself (Art 152).

The mis en examen may have a lawyer present at all stages of the instruction and through her defence lawyer, she may make written submissions at any point in the investigation which are then placed on the case file (Art 199). The lawyers for both the accused and the victim have access to the dossier of evidence and may make copies for their own use (Art 114).

\section{A. Placing the Mis en Examen in Custody}

As well as an investigative role, prior to the June 2000 reform, the juge also exercised a purely judicial function in deciding whether or not to detain the suspect in custody during the period of instruction. This was widely criticised in France (see, eg, Delmas-Marty Commission 1991; Commission de Réflexion, 1997), as a confusion of investigative and judicial functions.

The changes made to the instruction procedure seek to reinforce the presumption of innocence by retaining the juge d'instruction, but re-focusing her role. The function of the juge d'instruction as an investigator detached both from the police and the hierarchical control of the Minister of Justice is viewed as positive and worth retaining. ${ }^{112}$ It is her power to detain in custody those implicated in her investigation which has attracted adverse comment and been the subject of heated debate for many decades. ${ }^{113}$ Much publicity has surrounded the newly created juge des libertés et de la détention (JLD), as this has been probably the most often attempted reform in French penal history. ${ }^{114}$ Drawing on the proposals of the Delmas-Marty Commission (1991), ${ }^{115}$ the

\footnotetext{
112 In particular, the role of the juge d'instruction is contrasted favourably with the investigation process in place in adversarial systems of criminal justice. In addressing the Sénat (15 June 1999), Madame Guigou said, 'I prefer, and I want to make this quite plain, an independent judge who investigates evidence both for and against the suspect, to police officers who carry out large parts of the criminal investigation without any judicial supervision.'

113 More than 30,000 people are place in détention provisoire each year according to the Justice Minister in her speech to the Sénat, 15 June 1999. In her speech at the second reading of the Bill in the Sénat (29 Mar 2000) she noted that of the 52,000 people currently held in prison, 13,000 were there on the order of the juge d'instruction in détention provisoire, the average length of such detention being 4.2 months.

$114 \mathrm{eg}$, the short-lived introduction of the juge délegué in 1993.

115 Many of the current reform proposals emanate from the 1997 report (above n 51) of the Commission de réflexion sur la Justice (chaired by Pierre Truche, who, notably, also sat on the
} 
JLD will have a wider role than that of determining pre-trial detention during instruction: she will also adjudicate on issues affecting the rights and liberties of the suspect. The new procedure is designed to comply more closely with the ECHR requirement that pre-trial detention should be determined by a judge who is impartial and who is seen to be so in the eyes of others. This new post is held by a senior court judge and the aspiration is that the suspect will be better protected by the fact that two judges will have considered her case: the juge d'instruction in first referring the case for a remand in custody and the JLD who will make the decision (Art 137-1). ${ }^{116}$ The measure appears to have enjoyed some success in achieving its objective of fewer people being remanded in custody before trial during the period of instruction. ${ }^{117}$ However, the absence of sufficient personnel has meant that smaller jurisdictions in particular have been unable to establish judges dedicated to this task and have had to designate senior court judges on a rotating basis. This has been hugely disruptive for court sittings, as prior involvement as JLD in a case bars the judge from subsequently trying the matter. One magistrat described the situation as a kind of judicial musical chairs. ${ }^{118}$ There has also been criticism of two recent cases where the JLD decision was to release the suspect. The magistrature has been angered at the rapid censure that this generated from the President and from the Minister of Justice. ${ }^{119}$

The détention provisoire hearing may now be in public at the request of the suspect, unless the JLD considers it a danger to the investigation or to a third party (Art 145) and there is the improved possibility of compensation for those wrongly kept in custody (Art 149). The threshold of offences where détention provisoire is permissible has also been raised (Art 143-1) and the maximum period of detention is 2 years for those triable in the tribunal correctionnel ${ }^{120}$ and a limit of up to 4 years for the most serious offences has been imposed for the first time for crimes. The rather vague head of 'disruption of public order' has also been removed as a ground for détention provisoire other than in the most serious of cases (Art 144). Whilst she no longer enjoys the power to

1991 Delmas-Marty Commission, above n 24), which was charged with examining the protection of the presumption of innocence and the independence of the office of public prosecutor.

116 As well as stating the exceptions under which the suspect may be placed in custody, Art 137 $\mathrm{CPP}$ now underlines the presumption of liberty by explicitly mentioning that the mis en examen is presumed innocent.

117 See Collomp (above n 21); Le Monde 10 May 2001. 118 Le Figaro 9 Mar 2001

119 See Le Monde 26 Oct 2001 relating to the release of Jean-Claude Bonnal in December 2000 , subsequently suspected of committing six murders, two of the victims being police officers. Interestingly, some have suggested that this decision was in protest at the late hour at which the suspect was presented. This problem was specifically highlighted in the official evaluation of the reforms-Collomp (above n 21), para 2.1.1. Also Le Monde 5 Dec 2001 relating to the release on bail of a Congolese man found in possession of $1 \mathrm{~kg}$ of heroin and a quantity of cocaine. He failed to appear before the juge d'instruction the next day or subsequently. Government proposals set out in July 2002 (see above $\mathrm{n} 62$ ) would require the juge d'instruction to give written reasons when not following the parquet's request for a remand in custody and would provide the procureur with a right of appeal against the juge d'instruction's decision to release the suspect on bail.

120 This court tries délits punishable by a term of imprisonment or a fine of $25,000 \mathrm{FF}$ or more (Art $381 \mathrm{CPP}$ ). The July 2002 proposals (see above n 62) would extend this period to 3 years. 
detain those under investigation, the juge d'instruction will continue to be able to grant bail, with or without conditions.

\section{B. The Process of Instruction and témoins assistés}

The process of instruction itself has also been modified, in particular allowing the parties (the suspect or the partie civile) a greater ability to participate in the investigation. They may now request the juge to carry out any act which they think is necessary to uncover the truth and for the first time, may request that their lawyer be present when it is carried out (Arts 82-1, 82-2). Any refusal to comply with such a request is subject to appeal. They are also entitled to see the whole of the report prepared by an expert and not simply the conclusions (Art 167).

The procedure by and circumstances under which a person becomes mis en examen has also altered. The status of a suspect as mis en examen is important as it is at this point that she is afforded full defence rights: she may no longer be interrogated by the police, only by the juge d'instruction and her lawyer has full access to the dossier of evidence as well as being present at all interviews. The benefits which accrue to the accused, at one level, make it advantageous to be mis en examen. To do otherwise could be seen as maintaining her disadvantaged position. Yet, there is also a stigma attached to those under investigation. The 1993 reforms changed the way in which those implicated in the instruction were referred to, from inculpé, with its clear connotations of guilt, to the more neutral mis en examen. But this has not removed the stigma attached to those who find themselves the subjects of the juge d'instruction's investigations. This has been powerfully demonstrated in recent years by the politicians, such as Dominique Strauss-Kahn, who have felt obliged to resign once mis en examen.

The current legislation seeks to divert suspects against whom there is less strong suspicion, into the category of témoin assisté, whilst still preserving their defence rights. The status of témoin assisté was created in 1987 and attached to a person named as the perpetrator in a complaint. This recognised that there was not sufficient evidence against them to place them under formal investigation, but on the other hand, neither were they a simple witness. As an added degree of protection the person could be legally represented in any interview. The June 2000 reform seeks to encourage greater use of this procedure (Arts 80-1, 116). Thus, a person will not be automatically mis en examen on referral by the procureur. The juge d'instruction will be required to hear the suspect, in the presence her lawyer if she has one, before deciding whether or not to make her mis en examen (which now requires precise and corroborating evidence of guilt, not simply evidence suggestive of involvement) or simply a témoin assisté (which requires only some evidence suggesting guilt). ${ }^{121}$

At the close of the instruction, the juge d'instruction sends the case directly

121 The témoin assisté cannot be the subject of bail or détention provisoire and neither can she be sent for trial. She must first be mis en examen before these procedures can be invoked (Art 
to the cour d'assises (Art 181) without having to remit the file to the procureur first. If the instruction process results in no charges being brought against the mis en examen, she may request compensation for costs incurred, in particular, those of hiring a lawyer (Art 800-2).

\section{TRIAL AND SENTENCE}

At all points in the criminal process, these reforms seek to reduce delaysthrough imposing timetables, obligations to report on the progress of investigations and by imposing a limit on the amount of time a person may be remanded in custody awaiting trial. In the tribunal correctionnel, a person may only be remanded for a 2-month period, renewable twice. If she has not been tried after 6 months, she is released (Art 179). In the cour d'assises, the period is one year, renewable twice (in exceptional circumstances) for 6 months. If she has not been tried after 2 years in custody, the accused will be released (Art 215-2). The right for deaf people to have the proceedings interpreted into sign language is also included here, as during the police enquiry and instruction (Arts 345, 408). The trial procedure in both the tribunal correctionnel and the cour d'assises is also modified, with lawyers being able to question witnesses directly, rather than through the trial judge (Arts 312, 442). Those acquitted of the charges brought against them will be able to apply for compensation for costs - in particular to reimburse the cost of lawyer's fees (Art 800-2).

The cour d'assises tries the most serious offences, crimes, and comprises a jury of nine and three judges who together determine guilt or innocence and sentence. Until now there has been no appeal from this court. The new reform makes provision for appeal against conviction to a differently constituted cour d'assises with twelve jurors who may decide by a $10: 2$ majority (Arts 231, 296, 297, 298, 359, 360, 362) 122 $^{2}$ and in the February 2002 'petite loi' the procureur may also appeal against an acquittal. The oath which jurors are required to take is also altered to make reference to the presumption of innocence and the rule that the benefit of any doubt must be given to the accused and to the rights of victims (Art 304).

The fate of the accused post-sentence has also been the subject of reform. The conditions of those serving a sentence of imprisonment will be improved with the building of ten new prisons, allowing for more individual cells and a third weekly shower. Alternatives to custody, such as electronic tagging are also favoured. But it is upon the modification of the system of early conditional release of prisoners to which the government pins its greatest hopes. This is

113-5 CPP). However, as she is not a party to the proceedings, neither can she appeal against the judgment of the chambre d'instruction. See Cour de cassation., 13 Nov 2001, 01-85. 506 (No 7146) Dalloz, 2002 (4) 372

122 See further J Pradel (2001) ' 'L'appel' contre les arrêts d'assises: un apport heureux de la loi du 15 juin 2000.' Dalloz, Doctrine (25), 1964-72. 
favoured as a way of assisting the prisoner towards rehabilitation where there are reliable guarantees of her social re-adaptation. In practice, the eligibility criteria are narrow, requiring the prisoner to have a job. Given the precarious situation of many-21 per cent are illiterate and many are long-term unemployed-this is an unrealistic threshold which excludes many. It is perhaps unsurprising that this option has been utilised less and less frequently with 30 per cent of those serving a sentence of 5 years or less benefiting in 1970, but only 14 per cent in $1998 .^{123}$ The current reform seeks to relaunch conditional release as a partial alternative to imprisonment, by making it accessible to greater numbers of prisoners. The eligibility criteria are enlarged to include those intending to follow a course, undertake training or temporary employment, to support their family or follow a course of medical treatment (Art 729). In addition, the decision will no longer be that of one person (the juge d'application des peines or the Justice Minister) and of an administrative character. Instead it will be decided by a judge or a court, with the opportunity for legal representation, for both parties to make representations and for the decision to be appealed (Art 722). ${ }^{124}$

\section{CONCLUDING REMARKS}

\section{A. Resources}

The reform is wide ranging and makes a thorough attempt to incorporate its guiding principles across the different stages of criminal procedure. The result should be a criminal process which is more transparent and which allows the parties greater opportunities to participate. However, for those responsible for making these reforms a reality, the picture is a bleak one. Despite promises of additional resources, the universal complaint of all those charged with putting these changes into effect is that they are being required to do more and more with the same or fewer resources. Public hearings, improved rights of appeal and the additional personnel required to implement the JLD provisions and the collegiate decisions of the juge d'application des peines have had a substantial impact on the workloads of individuals-especially when secretarial and IT support has to be spread ever more thinly. Smaller jurisdictions are worst affected, with only one or two judges available to act as JLD, resulting in cancelled trials and court sittings late into the evening in order to get through case loads and greffes unavailable to assist the juge d'instruction because they are working with the JLD. ${ }^{125}$ Whilst the emphasis of recent legislation has

123 See speech of Justice Minister to Sénat (29 Mar 2000).

124 The official evaluation report notes that few prisoners have requested lawyers in this process. For the JAP, on the other hand, it is estimated that their workload will double as a result of the changes and they are struggling with poor human and material resources-Collomp (above n 21), 1.3.2, 2.1.1, 2.1.2.2, 2.2.2. 
been to reduce delay, the increased formalism of procedures threatens to slow things down, overburdening the courts and ultimately allowing fewer cases to be prosecuted. Legal personnel, for their part, complain of a spiralling workload and insufficient time for rest. Whilst the prospect of change and reorganisation frequently results in internal opposition to any major reform and resources are never deemed adequate, the official report on the application of the reform (Collomp, 2001) supports the more anecdotal evidence of press reports and warns of the potentially negative effects upon an already fragile situation. Many areas have found it difficult to implement the new provisions ${ }^{126}$ and stretched resources in many instances, call into question the quality of justice delivered. ${ }^{127}$ All of this has not been without its effect on a government hoping for re-election by a public increasingly preoccupied with rising crime rates. The January 2002 circular and the terms of the February 2002 'petite loi', whilst claiming not to undercut any of the achievements of the June 2000 project, clearly dilute a number of the provisions. Furthermore, they are not expressed in the same optimistic tones of protecting rights and strengthening the presumption of innocence. Instead, the language is a little tougher, with a return to the rhetoric of crime control, of répression, which was so markedly absent only 18 months earlier. ${ }^{128}$

\section{B. The Garde à vue}

At the level of policy, French criminal justice is in a delicate stage of transition. Very much influenced by the ECHR, it is moving forward towards greater openness and participation rights for the parties, whilst at the same time resisting the abandonment of its inquisitorial structures. It has been obliged to make some changes to its criminal procedure: some, in response to particular European Court decisions, others, to give effect to basic Convention guarantees. But for many, especially outside France, the reforms do not go far enough. In particular, there is little in this reform project which addresses the other major area of concern highlighted within the European arena, that of police brutality. The 1990s witnessed the police shooting of a number of suspects both in and outside the police station ${ }^{129}$ and the European Committee for the Prevention of Torture and Inhuman or Degrading Treatment or

\footnotetext{
125 Courts sitting after midnight are reported in the official report-Collomp (above n 21), para 2.1 .1

126 The requirement to visit police stations every 3 months has not been possible in some areas where only a few procureurs must cover a wider area. One example given was of 296 visits per year, covering 18,000 km-Le Figaro 22 Jan 2001. See also Collomp (above n 21), para 1.4.2.

127 See Collomp (above n 21), paras 1.2.2, 2.1.1. Some additional resources have been promised after strong protests. See above n 20.

128 The new government has continued this trend and its proposed legislation has been criticised widely as a retrograde step, particularly in its approach to juvenile offenders. The reform (see above $\mathrm{n}$ 62) is being put through Parliament in a special session to speed things along.

129 Several officers are currently mis en examen for the murder of a 16 -year-old who tried to drive through a road block in December 1997. See Le Monde, 8 Sept 1999.
} 
Punishment (part of the Council of Europe in Strasbourg) has continually raised concerns over police violence during the garde à vue in 1993, 1998, and again in their latest report published in 2001. ${ }^{130}$ France was condemned for torture and inhuman and degrading treatment in July 1999 for the violent abuse which Ahmed Selmouni suffered at the hands of the police. ${ }^{131} \mathrm{He}$ and his co-accused, Abdelmajid Madi, claimed that they were beaten about the face, head, body, and genitals with fists and truncheons, threatened with a syringe and blow torch, sexually assaulted, and urinated upon. ${ }^{132}$ It took $5 \frac{1 / 2}{2}$ years for the French courts to try the five police officers concerned, resulting in the European Court finding that France had been far too slow in prosecuting the case. And whilst their convictions were upheld on appeal, all but one had their prison sentence reduced to a suspended sentence.

The responsibility for overseeing the conduct of the police detention and interrogation of suspects rests with the procureur and in most instances, this is carried out over the telephone or by fax. Yet, despite awareness of the limitations of this form of supervision, the majority of procureurs have neither the time nor the desire to visit the police station to check on the conditions of the garde à vue. ${ }^{133}$ The current reform makes little substantial change in this respect. It does not encourage a norm of personal attendance, requiring only one visit annually. Neither is the modest intrusion of the defence lawyer into the police station for 30 minutes (even at the start of detention, rather than after 20 hours) likely to curb any but the most serious incidents of violence and malpractice. The tape recording of interrogations was considered and rejected as a possible means of ensuring that confessions are properly obtained, the only concession being in the case of juveniles, whose interrogations will be video recorded. ${ }^{134}$ Police interrogations of the suspect, therefore, remain shielded from scrutiny, with neither the tape recorder running, nor the defence lawyer present. These are safeguards which, whilst considered necessary in a pre-trial process which is under the exclusive control of the police, are deemed to be less appropriate within the structure of judicial supervision in France.

\section{The ECHR in an Inquisitorial Context}

It is in this pre-trial stage of the criminal process that we see most clearly the tension between the demands of conformity with the principles and guarantees

\footnotetext{
130 The report (2001, above n 76) expresses concern over the treatment of suspects and detainees, especially foreign nationals and those held on suspicion of terrorist activity (paras 14-21, 37, 39).

131 Selmouni v France ECHR 28 July 1999.

132 See Le Monde 31 Sept 1999. The court found that the sexual assault had not been proved.

133 See Hodgson (above n 10), esp pp 350-4. This is especially surprising given that 40 per cent of questionnaire respondents reported suspecting that violence or excessive pressure had sometimes been used against suspects held in police custody.

134 Police misconduct in the performance of 'judicial' duties will, however, be investigated by a judicial (rather than police) inspectorate under Art 15-2.
} 
of the ECHR and the desire to retain a broadly inquisitorial structure which has at its centre the ideal of the judicially supervised investigation. Those sponsoring recent reforms have had to walk a tightrope between, on the one hand, ensuring that France remains faithful to the European Convention and maintains its self-image as the homeland of human rights, ${ }^{135}$ and on the other, proffering reassurances that the changes which this entails in no way represent a move towards a more adversarial process. ${ }^{136}$ This tension has been resolved through the implementation of reforms which make only the minimum adjustments necessary, with much reference to the rhetoric of 'equality of arms' and 'defence rights', rather than any radical reappraisal creating a more modern criminal procedure. For example, in line with Convention expectations, the suspect held in police custody now has access to a defence adviser-but only in the most limited sense: they may speak in private for 30 minutes, but the lawyer may not see the evidence against the suspect nor be present during the interrogation. The lawyer serves a legitimating purpose ${ }^{137}$ in enabling France to make claims about respecting 'defence rights', but it is clear that, in the majority of cases, she is neither expected nor allowed to play any significant role in the pre-trial process.

However, a strategy of minimal adjustment has its price. These externally generated modifications over the last decade, have led to criticism of the way in which French criminal procedure has evolved in a piecemeal and incoherent fashion, ${ }^{138}$ with features of a more adversarial procedure being reluctantly grafted on to a process established two centuries ago. This issue was tackled head on in 1991 in the report of the Delmas-Marty Commission, which proposed sweeping changes to make the criminal process more coherent, transparent and in conformity with the ECHR. A clearer separation between the roles of investigation and of judgment was considered essential. In particular,

135 See, eg, the speech of the then Justice Minister, Madame Guigou, to the Sénat, 30 May 2000

136 In almost every speech before Parliament and every media interview, Madame Guigou affirmed her commitment to the present system in France and her dislike of things adversarial. See, eg, her speech to the Sénat in June 1999 (above, n 22) and her interview with Le Monde 15 Dec 1999, where she rejected the idea of the defence lawyer playing a greater role in the process: 'Lawyers are there to help their clients and to ensure the proper conduct of the garde à vue, but not to start getting involved in the case. I have chosen not to adopt the adversarial procedure because it reinforces the inequalities of access to the law. It would lead ultimately, for example, to the use of private investigators in order to verify the investigation led by the police.' In addition, the government has had to contend with fierce opposition to these reforms on the part of the police.

137 Historically, this has been the function of an independent defence in general: '[the judiciary] set aside a space of its own and imposed an operating rule that was almost magical, in that it postulated the neutralization of the effects of real society, declared the equality of the parties, and guaranteed the impartiality of the judgment. If lawyers' independence was a constituent condition from the outset, it is because it was regarded as the condition, and soon as the sign, of an independent judiciary', Karpik (above n 43), 146-7. See also the Delmas-Marty report (above n 24).

138 Professor Mireille Delmas-Marty has been the most prominent in this respect. See, eg, M Delmas-Marty (1990) 'Réformer: anciens et nouveaux débats.' Pouvoirs, 55, 5-21; 'The Juge d'Instruction: Do the English Really Need Him?', in BS Markesinis (ed), The Gradual Convergence (Oxford: Clarendon Press, 1994), 46-58. See also Pradel (above n 54). 
the Commission advocated making the procureur responsible for all investigations (with increased rights for the defence) removing any investigative functions from the juge d'instruction and turning her into a juge des libertés who would decide on issues which affected the liberty of the suspect. This radical proposal was rejected as the first step towards an adversarial process that would have the procureur and the defence lawyer as the two pre-trial players in place of the ideal of the neutral investigating judge. Practitioners have been equally sceptical. The introduction of custodial legal advice was initially greeted with hostility by both police and magistrats who considered it unnecessary and inappropriately adversarial. The experience of practitioners, however, is that is has made little difference to the investigation and has had the added benefit of lending legitimacy to the garde à vue procedure. Despite similar reservations about the June 2000 changes relating to legal advice and the right to silence, ${ }^{139}$ initial concerns appear to be similarly misplaced.

Decisions of the European Court relating to other jurisdictions may yet challenge aspects of this inquisitorial procedure and the judicial character that is ascribed to all magistrats. The criminal division of the Cour de cassation has held that the procureur is a judge for the purpose of the ECHR and her authority to prolong detention for a further 24 hours does not breach Art 5(3) of the Convention. ${ }^{140}$ However, the European Court has held that local state prosecutors in Switzerland cannot be regarded as impartial judges for this purpose as they can bring a prosecution against the person in custody. ${ }^{141} \mathrm{In}$ France, the procureur's judicial role in authorising initial detention periods remains, but the decision appears to have influenced subsequent legislation which requires a designated judge to authorise detention for a further 48 hours in the case of terrorism or drugs trafficking cases. ${ }^{142}$

In many respects, a strongly inquisitorial process of criminal justice is incompatible with the guarantees of the ECHR, and in particular, the need for prompt and effective defence representation. Historically, the French have eschewed as unnecessary any elevation of the defence role beyond the current execution of procedural checks, preferring to safeguard the interests of the accused through the institution of the magistrat. But what is missing from the debate surrounding these and proposed reforms, is a critical empirical appraisal of the success of core features within the French process, such as judicial supervision and the extent to which in practice, they provide adequate safeguards for those investigated and prosecuted This debate need not lead to the narrow dichotomising of choice between adversarial and inquisitorial

139 On the day that most of the reforms came into operation, Mme Gilles-William, the president of the association 'droit à la sécurité' told Le Figaro (1 Jan 2001), 'The root of the problem is that we are aping the American system, when our own law does not lend itself to that. The overall result will be negative.'

140 Art 5(3) ECHR requires that a person who is arrested or detained be immediately brought before a judge who is empowered to exercise judicial functions.

141 Huber $v$ Suisse 1990 (23 Oct 1990. Series A, 188)

142 See Elliot and Vernon (above n 58), 150. 
procedures, to the election of one of two mutually exclusive models of either judicial supervision or of defence participation. The strengths and weaknesses of different regulatory frameworks of criminal justice can be assessed in context and a more nuanced approach adopted. Within an inquisitorial procedure, the appropriate interpretation of apparently universal principles such as 'equality of arms' can be explored. Whilst a greater pre-trial role for the defence lawyer would necessarily introduce a more adversarial element into the procedure, the existing legal framework and the prevailing legal culture would constrain the impact of such a change. ${ }^{143}$ The presence of a defence lawyer during the judicial questioning of the accused, for example, has not transformed the instruction into an adversarial procedure. Safeguards such as the presence of a defence lawyer during police interrogation, a wider role for the defence in the pre-trial gathering of information, or a greater emphasis on the oral assessment of evidence at trial, ${ }^{144}$ may be deemed necessary, not as part of a move to a more adversarial process, but in the spirit of these and other recent reforms, as a way of strengthening the guarantees of the current structure of judicial supervision.

\footnotetext{
143 It is interesting that the Truche Commission (above n 51) recommended that police interviews be tape recorded, but not that lawyers be present. It seems more likely that of the two, taperecording would be preferred over the intrusion of the defence lawyer, whose non-magistrat status and role in representing the interests of the suspect, means that she continues to be regarded as a partisan outsider.

144 See, eg, B McKillop (1998) 'Readings and Hearings in French Criminal Justice: Five cases in the Tribunal Correctionnel', American Journal of Comparative Law, 46, 757-83.
} 
